\title{
Attitudes of Gifted and Talented Pupils towards Learning Experiences and Teaching Methods at an Enrichment Center
}

\author{
Hait shaham and Stan Sofer \\ Gordon Academic College of Education, Haifa, Israel \\ Doi:10.5296/ijld.v4i1.5237ＵRL: http://dx.doi.org/10.5296/ijld.v4i1.5237
}

\begin{abstract}
This research examined the attitudes of gifted and talented pupils towards different methods of teaching and learning experiences at an enrichment center. The research sample included 275 gifted and talented children aged ten to twelve who studied at an after-school enrichment program, Hugordon, based at the Gordon Academic College of Education in Haifa and the Maagan Michael Community Center in 2008. Within the workshops, teachers employed various teaching methods and strategies. A survey was conducted among the pupils that included both open- and closed-ended questions about their attitudes towards various teaching methods. Findings indicated that the pupils had a high to very high level of satisfaction from their learning experience in the workshops. Moreover it was found that pupils who specialized in science and technology were challenged by activities that promoted analytical and practical thinking methods, whereas pupils that specialized in humanities showed a higher level of satisfaction from the role of the teacher.
\end{abstract}

Key words: attitudes of gifted and talented pupils, teaching methods, learning experience, after school enrichment program

\section{Introduction}

This study deals with the attitudes of pupils who participated in the Hugordon Program for gifted and talented children. It was conducted in Israel in 2008 at the Gordon Academic College of Education in Haifa, and at an extension facility located at the Maagan Michael Community Center. The program was attended by $4^{\text {th }}$ to $6^{\text {th }}$ grade pupils from the Haifa and the Carmel Coast Regional Councils who were considered gifted or highly talented. The program provided an opportunity for these pupils to be in a rich learning environment that acquainted them with learning aids such as advanced laboratories, computers and databases, as well as a group of experts from the fields of academia and the arts. The pupils were exposed to various learning methods through courses in science and technology (science), and the humanities and art (humanities). The courses in science were: Mathematical Thinking, Magic and Science, Robotics, ZOO Gordon, Aerodynamics and Space, Young Veterinarians, Discoveries and Inventions in Science, and Environment and Ecology. The humanities courses included: Rhetoric and Speech, Culture, Interdisciplinary Communication, Dungeons and Dragons, the Sounds of English, Archeology, and Creative Thinking.

This study is innovative in that it examined various aspects of teaching methods as perceived by gifted pupils. Its objectives were to examine attitudes of pupils participating in an after-school program for gifted and talented children towards teaching methods, learning experience, and the role of the teacher. The study aimed to identify those activities within the courses that pupils perceived as challenging, and to compare the attitudes of pupils who studied science with pupils who studied humanities. 


\section{Theoretical Background}

The goal of an enrichment program for gifted and talented pupils should be to expand the development of their cognitive processes, such as the ability to speculate and solve problems (Van Tassel-Baska, Feldhusen, Seeley, Wheatley, Silverman, \& Foster, 1988). Special programs for gifted and talented pupils emphasize critical and creative thinking and problem solving as their basic blocks, and participants learn to define problems and plan a project. The teacher's role is to guide them so that the project will be the result of their pupils' work. The role of the teacher is to focus mainly on offering pupils challenging problematic situations and encouraging analytical thinking. Van Tassel-Baska and others (1988) offered the following objectives in developing special programs for gifted children: to allow expertise in any field at a rate and depth which is adaptable to learners with higher capacities; to promote critical thinking skills; to foster branching thinking skills and creative thinking; to develop inquiry skills and research methods authenticity; to foster solving problem skills; to develop an understanding of knowledge systems, themes, issues and problems that characterize the real world; to develop high verbal writing skills; to develop higher order thinking skills; to expand opportunities for future development; to foster social skills and the ability to cope effectively in the social context; and to develop meta-cognitive skills which encourage self-directed learning.

These goals involve thinking, which includes a psychological process of receiving and processing stimuli. Different people have different thinking styles, which are reflected in the way they acquire knowledge, formulate ideas, feel, and behave. To understand why certain educational activities are suitable for an individual's learning process it is important to know his thinking style (Weinberger \& Zohar, 2005; Smith, 2002; Sternberg, 1997).

Thinking styles are affected by different types of intelligence. Gardner (1993) classified the types of intelligence as follows: logical intelligence, linguistic intelligence, musical intelligence, spatial intelligence, physical intelligence, interpersonal intelligence, and intrapersonal intelligence. In his opinion, to strengthen the pupil's self-perception one should strengthen and develop the pupil's types of intelligences partly by providing a rich and developed learning experience, and through utilizing a variety of teaching methods.

Sternberg (1998) suggested the following types of thinking styles: Analytical thinking, which concerns comparing and contrasting, judgment, evaluation and analysis based on the ability to analyze and evaluate ideas, solve problems and make decision; Creative thinking, which involves discovery, invention, imagination and hypothesis related to the ability to deviate from a given situation and to generate new and interesting ideas. Creative thinking looks for differences, performs deliberate jumps, welcomes interventions, and checks for less-likely solutions. Practical thinking, which focuses on the use, exploitation, and application of ideas is derived from the ability to translate theory and abstract ideas to practical achievements.

Teaching and learning methods are based on the theories of thinking styles and types of intelligence. To create effective learning processes, learners should be provided with a wide range of activities and teaching methods so that at least some of them will fit their specific style of thinking. However, it need not necessarily be a perfect match. Learners must deal with activities that require them to adopt different thinking styles (Sternberg, 1997). This flexibility is also important for the learner and the teacher. Teachers should strive to reach the match between the two in order to accurately assess the learners (Smith, 2002). There are teaching methods which are appropriate for specific types of thinking styles.

The inquiry teaching method allows pupils to be active partners in all stages of the inquiry learning process. During the learning they experience various skills including asking questions, synthesizing data, organizing information, and drawing conclusions. The teacher's role in inquiry teaching is to equip the learner with these skills so that the learner will utilize 
them when he or she becomes an adult in a highly technological society. The activities within the inquiry method provide pupils with opportunities to look for answers to questions while operating thinking skills (Zohar, 2006). However inquiry instruction in primary schools in Israel today focuses on the final product rather than the process itself (Gordon, Levin-Rozalis \& Keenan , 2003). Most of the inquiry learning at the elementary school level highlights writing papers, and there is no emphasis on learning experience within the inquiry learning process.

In the theoretical and research literature there is a limited use of the term "learning experience," described by John Dewey (1938) as a good experience that leads to better experiences. Maslow (1968) defined it as peak experiences or peak highlights that a person experiences from natural situations. Based on Maslow's research, Hoffman (1998) found that similar to adults, children are also able to record experiences that affect their lives. These experiences occur spontaneously at different moments, and generally are not deleted from memory.

Learning experience occurs when the learning is significant and collaborative enabling intellectual growth, production of ideas, and the development of critical thinking (Freire, 1981). He argued that knowledge is expected to raise and grow only through means of inquiry and discovery. In such learning there is an understanding that allows the pupil to apply the knowledge, concepts, and skills acquired in an educational framework, and also in new situations. Moreover, meaningful learning occurs when the student is given autonomy in the learning process (Bruner, 1960). The study of Gruber and Jean (2003) dealt with the learning experiences of pupils. These researchers tried to extend the theory of Dewey (1938), according to which experience is also a means and a goal of education. They argue that the use of personal learning experiences may develop critical relationships and strengthen awareness of the social and cultural implications of education.

Kubovy's study (1978) was among the first in Israel that examined the learning experiences of pupils. Like most psychologists and theorists, Kubovy claimed that the lack of positive experiences in the development process may harm the sense of basic confidence of the pupil. Yair (2003, 2008) coined the term "key experiences," which he considered the "big bang" that a person experiences following a short educational activity. This leads to an enlightenment or revelation that allows a person to choose a new future and shape it in a manner which is disconnected from the restrictions of the past. Of course, such experiences affect the life of the pupil and leave their imprint.

From the above, it follows that the teacher of gifted and talented pupils must enable learning opportunities that will create a learning experience. The teacher must ensure a learning environment which is safe, non-threatening, and encourages respect. One of the major factors in creating a supportive atmosphere in the classroom is freedom. Pupils must feel free to ask cognitive and sensitive questions at any time during the learning experience that will help them take risks in processing ideas and formulating answers. In order to create a desirable learning atmosphere, the teacher must respect the ideas of the pupils and demonstrate this attitude through active listening. This provides a safe environment for risk-taking when making hypotheses. The learning environment is greatly affected by the teacher's behavior. Creating a student-friendly experience is essential to the success of a class that is being taught through the method of inquiry. Teachers and pupils should be encouraged to build open relationships to create an appropriate atmosphere for the investigation of challenging ideas, and an open climate for generating ideas (Shaunessy, 2006). The atmosphere in the class has proved to be a great influence on children's motivation and their creativity of performance (Deci, Nezlek, \& Sheinman, 1981). Pupils who feel that they control their fate will be motivated to learn and to succeed (Hennessey, 2004). 
The key to the success of any educational program is the teacher. Research on the perception of pupils of their teachers showed that teachers need to be knowledgeable and facilitate learning through posting new challenges (Vialle \& Quigley, 2002). They found that skilled teachers of gifted pupils are expected to have high cognitive abilities and pedagogical levels, and have personal and social abilities. They must be aware of their pupils' cognitive needs, and adapt pedagogical strategies to encourage higher level thinking and promote independent learning. These teachers should be creative, intelligent, ambitious, knowledgeable, flexible, and able to communicate well with talented people. They should know how to teach thinking skills, problem solving, and creativity. They should be able to use the various thinking techniques and to conduct activities aimed at allowing independent study. Researchers noted that the skills necessary to learn certain content areas may be different. Teaching techniques used for teaching science and mathematics may be very different from those techniques used in the arts and humanities (Eilam \& Vidergor, 2011).

An exemplary teacher should control content, have an enthusiastic personality, invest in teaching methods, and have a flexible and adventurous spirit in the execution of teaching. Three essential skills needed to work with gifted children are: knowledgeable and effective use of teaching techniques, communication skills, and the ability to understand the needs of pupils and relate to them (Van Tassel-Baska, MacFarlene \& Feng, 2006). Sternberg (1998) addressed the impact of the teacher on pupils' thinking styles. He argued that teachers teach and assess pupils in a manner which encourages and compensates pupils with certain learning and thinking styles and impedes other pupils with different types of thinking styles. For this reason there has been confusion between the lack of compatibility between the student's thinking style and the student's inability to perform tasks. As pupils are given more options of choice and mobility, the complexity of the situation grows, and the need for the teacher for activities to control the situation is also increased. Teachers and pupils together negotiate the terms of the construction of knowledge. The key to the success of a teacher's classroom management relates to understanding the structure of the events taking place in the class, in the teacher's skills to monitor and engage the pupils, and the activities according to this understanding (Doyle, 1986).

In the vision of the Department for Gifted and Excellent Pupils of the Israeli Ministry of Education, the teachers' expertise and unique pedagogy for teaching gifted pupils are the conditions for providing optimal conditions for learning. The teacher should be an expert in the field of knowledge, the promotion of thinking, and strengthening social, emotional and ethical characteristics among his pupils (Zorman, Rachmal \& Shaked, 2004).

Gifted children have a preference for a specific method of teaching and learning. Rogers

(2007) presented a preferred model of teaching according to the area of study. According to him, gifted pupils prefer group investigation over frontal teaching, especially in mathematics. Gifted pupils in literature preferred learning within the group inquiry method. Rapid learning in these areas contributes to gifted children. Rogers found that the achievements of gifted pupils learning within the inquiry research method were significantly higher than those of gifted pupils learning in other methods. Therefore, mathematics and science content must be presented differently than other disciplines. According to Sternberg (1985), gifted pupils in mathematics and science are comprehensive thinkers. They acquire information in a comprehensive manner and store it in their long term memory.

In a study conducted in Australia, Rowley (2002) found that gifted pupils preferred an open learning climate but preferred skilled teachers trained in teaching gifted pupils rather than untrained teachers. These teachers emphasized methods of higher order thinking (analysis and synthesis) rather than ways of thinking based on the skills of memory, and discussions rather than frontal lectures. 
In a study conducted in Israel on the perceptions of gifted pupils regarding the desirable traits of their teachers according to cultural background and gender, three dimensions were tested: cognitive (promoting teaching skills in the process of learning), pedagogical (learning advancement), and personal (teacher personality). Comparison of the pupils' average ratings revealed that the personal dimension rated highest, and that the pedagogical dimension rated lowest. Personal characteristics of the teachers were perceived as most important (Eilam \& Vidergor, 2011).

Although the literature review found studies on pupils' perceptions of the desirable properties of a teacher for gifted pupils, there was no reference in the literature to their experience of learning and teaching methods. This study emphasizes the attitudes of pupils towards learning experience, learning methods, and the role of the teacher in the learning process.

\section{Research Questions}

Pupils enrolled in the Hugordon Enrichment Center were asked the following questions:

- What is the level of satisfaction from their learning experience?

- What is the level of satisfaction from teaching methods in the courses?

- What is the level of satisfaction from the teachers' role in the courses?

- Which activities did the pupils find as most challenging?

- Is there a difference between the attitudes of pupils in different types of courses to the learning environment, teaching methods, and the role of the teacher (science and humanities)?

\section{Research Hypotheses}

- First hypothesis: The level of satisfaction of gifted and talent pupils towards their learning experience and teaching methods in the center will be high with regard to the activities and content presented in the courses.

- Second hypothesis: There will be differences in the levels of satisfaction of the pupils towards their learning experience and teaching methods between the group studying science and technology and the group studying humanities and art.

\section{Method}

\section{Sample}

This study examined 275 gifted and talented children aged 10-12 who were studying in the Hugordon Enrichment Center at the Gordon College of Education in Haifa and the Hugordon Enrichment Center at the Maagan Michael Community Center in Israel. The pupils answered a questionnaire that was constructed for the purpose of this study upon course completion. Of the 275 pupils, 180 attended courses in science and technology, and 95 in the humanities and art.

\section{Research Tools}

A questionnaire was designed to test the pupils' attitudes towards learning experience and teaching methods. The questionnaire focused on the following topics: learning experience, role of the teacher, and teaching methods including the inquiry method. Pupils were also asked to write down the three most challenging tasks they experienced during the courses. Every statement in the questionnaire was analyzed by a numerical rating. The rating was determined according to the following scale: 4-very large degree, 3-large degree, 2-sometimes, 1-small degree, and 0-never. 


\section{Data Processing}

The findings of the questionnaires (closed answers) were analyzed using averages, standard deviations, and t-test comparisons. Low grades (1-2) reflected a low degree of satisfaction, and high grades (3-4) reflected a high degree of satisfaction. Statements from the questionnaire were classified in three categories: learning experience, role of the teacher, and teaching methods. The open answers were sorted into categories based on content analysis.

Content analysis was performed on the types of activities that challenged the pupils. The pupils recorded 676 activities taught in the courses in which they participated. These were rated into 14 categories, including visual aids, learning through situations, experiments, and modeling. These categories were compared in the two fields of interest--science and humanities.

After rating the activities, the relative frequency of each activity was calculated per total pupil population for each field. A statistical significance test was performed examining dependence within the variables (chi-square) to examine whether there were significant differences in the frequency of activities among the two groups.

\section{Findings}

Pupils' attitudes toward the learning experience and the teaching methods were examined in this survey. Findings related to the first hypothesis are represented by the pupils' attitudes toward the teaching in the courses. Findings related to the second hypothesis were represented by the differences in attitudes of science pupils versus humanities pupils towards the learning within the courses and the list of activities that the pupils perceived as challenging. Table 1 shows the findings of the questionnaires on pupils' attitudes about the learning experience, the role of the teacher, and the teaching methods. 
Table 1

Pupils' attitudes towards teaching in the courses*

\begin{tabular}{|c|c|c|c|c|}
\hline Statement & $\mathrm{M}$ & $\mathrm{Sd}$ & $\mathrm{N}$ & Category \\
\hline I enjoyed participating in the course & 3.54 & 0.72 & 275 & $\begin{array}{l}\text { Learning } \\
\text { experience }\end{array}$ \\
\hline I learned new things in the course & 3.43 & 0.79 & 275 & $\begin{array}{l}\text { Learning } \\
\text { experience }\end{array}$ \\
\hline $\begin{array}{l}\text { I learned a wide variety of topics within the } \\
\text { framework of the course. }\end{array}$ & 3.33 & 0.90 & 275 & $\begin{array}{l}\text { Learning } \\
\text { experience }\end{array}$ \\
\hline $\begin{array}{l}\text { The course curriculum level within the } \\
\text { framework of the course was higher than in } \\
\text { school. }\end{array}$ & 3.17 & 1.00 & 275 & $\begin{array}{l}\text { Teaching } \\
\text { methods }\end{array}$ \\
\hline The tasks within the course were challenging & 2.87 & 1.03 & 275 & $\begin{array}{l}\text { Teaching } \\
\text { methods }\end{array}$ \\
\hline $\begin{array}{l}\text { The teaching methods within the course suited } \\
\text { me. }\end{array}$ & 3.35 & 0.89 & 275 & $\begin{array}{l}\text { Learning } \\
\text { experience }\end{array}$ \\
\hline $\begin{array}{l}\text { I learned topics within the course that I don't } \\
\text { learn in school. }\end{array}$ & 3.64 & 0.68 & 275 & $\begin{array}{l}\text { Learning } \\
\text { experience }\end{array}$ \\
\hline $\begin{array}{l}\text { I learned topics within the course with different } \\
\text { teaching methods than at school. }\end{array}$ & 3.38 & 0.86 & 275 & $\begin{array}{l}\text { Teaching } \\
\text { methods }\end{array}$ \\
\hline $\begin{array}{l}\text { The teacher encouraged me to learn in depth } \\
\text { and to research the course topics. }\end{array}$ & 3.17 & 1.07 & 275 & $\begin{array}{l}\text { Teacher } \\
\text { role }\end{array}$ \\
\hline $\begin{array}{l}\text { The teacher stimulated my curiosity concerning } \\
\text { the course subject. }\end{array}$ & 3.25 & 0.95 & 275 & $\begin{array}{l}\text { Teacher } \\
\text { role }\end{array}$ \\
\hline $\begin{array}{l}\text { I feel that I am able to use the new practical } \\
\text { knowledge acquired in the course. }\end{array}$ & 3.27 & 0.96 & 275 & $\begin{array}{l}\text { Teacher } \\
\text { role }\end{array}$ \\
\hline $\begin{array}{l}\text { I enjoyed working on the computer and I surf } \\
\text { internet sites in the course subject. }\end{array}$ & 2.61 & 1.41 & 114 & $\begin{array}{l}\text { Teaching } \\
\text { methods }\end{array}$ \\
\hline $\begin{array}{l}\text { Watching films/presentations in the course } \\
\text { were relevant and important for understanding } \\
\text { the topics covered in the course. }\end{array}$ & 3.30 & 1.04 & 201 & $\begin{array}{l}\text { Teaching } \\
\text { methods }\end{array}$ \\
\hline $\begin{array}{l}\text { The teacher encouraged me to think and } \\
\text { therefore I expanded my knowledge. }\end{array}$ & 3.24 & 0.99 & 275 & $\begin{array}{l}\text { Teacher } \\
\text { role }\end{array}$ \\
\hline $\begin{array}{l}\text { The trips/observations/visits to museums } \\
\text { contributed to me and expanded my knowledge } \\
\text { in the subject. }\end{array}$ & 3.03 & 1.22 & 136 & $\begin{array}{l}\text { Teaching } \\
\text { methods }\end{array}$ \\
\hline $\begin{array}{l}\text { The experiments/demonstrations/lectures } \\
\text { contributed to enrich my knowledge in the } \\
\text { subject. }\end{array}$ & 3.23 & 1 & 227 & $\begin{array}{l}\text { Teaching } \\
\text { methods }\end{array}$ \\
\hline $\begin{array}{l}\text { Making surveys/projects/creative works helped } \\
\text { me gain a better understanding of the subject. }\end{array}$ & 3.02 & 1.24 & 240 & $\begin{array}{l}\text { Teaching } \\
\text { methods }\end{array}$ \\
\hline I enjoyed working on group projects. & 3.14 & 1.11 & 275 & $\begin{array}{l}\text { Teaching } \\
\text { methods }\end{array}$ \\
\hline
\end{tabular}

* The number of pupils who rated each statement differs because some statements were not appropriate for all activities in all courses.

Table 1 shows that the average range of the level of agreement is from 2.61 (moderate degree) to 3.64 (large degree), and the standard deviation is from 0.62 to 1.41 . Statements related to learning experience tended to have a high level of agreement among the pupils (3.14 to 3.64), such as "I learned topics within the course that I don't learn in school," and "I enjoyed 


\section{Macrothink Institute}

participating in the course." Statements related to the role of the teacher were agreed with to a great extent, but to a lesser degree (3.17 to 3.27) than the statements related to the learning experience. Statements relating to teaching methods showed a high level of agreement, but there was a wider range level of agreement with the statements $(2.61-3.38)$. Only regarding teaching methods were there two statements with an average below 3, "I enjoyed working on the computer," "I surf internet sites in the course subject," and "The tasks within the course were challenging".

Table 2 presents the findings of the questionnaires describing the pupils' attitudes towards the learning experience, the role of the teacher, and the teaching methods according to the main areas of study:- science /technology and arts/humanities.

Table 2

Differences in attitudes of pupils who studied scienceltechnology courses compared to arts/humanities.

Science

Humanities

\begin{tabular}{|c|c|c|c|c|c|}
\hline Statement & $\mathrm{M}$ & $\mathrm{Sd}$ & $\mathrm{M}$ & $\mathrm{Sd}$ & $\mathrm{t}$ \\
\hline I enjoyed participating in the course & $\begin{array}{c}3.49 \\
(\mathrm{~N}=180)\end{array}$ & 0.78 & $\begin{array}{l}3.65 \\
(\mathrm{~N}=95)\end{array}$ & 0.59 & $1.99 *$ \\
\hline I learned new things in the course & $\begin{array}{c}3.36 \\
(\mathrm{~N}=180)\end{array}$ & 0.84 & $\begin{array}{l}3.55 \\
(\mathrm{~N}=95)\end{array}$ & 0.67 & $2.08 *$ \\
\hline $\begin{array}{l}\text { I learned a wide variety of topics within the } \\
\text { framework of the course. }\end{array}$ & $\begin{array}{c}3.26 \\
(\mathrm{~N}=180)\end{array}$ & 0.97 & $\begin{array}{l}3.47 \\
(\mathrm{~N}=95)\end{array}$ & 0.75 & $1.96 *$ \\
\hline $\begin{array}{l}\text { The course curriculum level within the } \\
\text { framework of the course was higher than in } \\
\text { school. }\end{array}$ & $\begin{array}{l}3.18 \\
(\mathrm{~N}=180)\end{array}$ & 0.97 & $\begin{array}{l}3.14 \\
(\mathrm{~N}=95)\end{array}$ & 1.06 & 0.27 \\
\hline The tasks within the course were challenging & $\begin{array}{c}2.86 \\
(\mathrm{~N}=180)\end{array}$ & 1.04 & $\begin{array}{c}2.86 \\
(\mathrm{~N}=95)\end{array}$ & 0.99 & 0.01 \\
\hline $\begin{array}{l}\text { The teaching methods within the course } \\
\text { suited me. }\end{array}$ & $\begin{array}{l}3.3 \\
(\mathrm{~N}=180)\end{array}$ & 0.95 & $\begin{array}{l}3.45 \\
(\mathrm{~N}=95)\end{array}$ & 0.73 & 1.45 \\
\hline $\begin{array}{l}\text { I learned topics within the course that I don't } \\
\text { learn in school. }\end{array}$ & $\begin{array}{c}3.62 \\
(\mathrm{~N}=180)\end{array}$ & 0.72 & $\begin{array}{c}3.70 \\
(\mathrm{~N}=95)\end{array}$ & 0.56 & 1.09 \\
\hline $\begin{array}{l}\text { I learned topics within the course with } \\
\text { different teaching methods than at school. }\end{array}$ & $\begin{array}{c}3.43 \\
(\mathrm{~N}=180)\end{array}$ & 0.80 & $\begin{array}{c}3.28 \\
(\mathrm{~N}=95)\end{array}$ & 0.95 & 1.26 \\
\hline $\begin{array}{l}\text { The teacher encouraged me to learn in depth } \\
\text { and to research the course topics. }\end{array}$ & $\begin{array}{c}3.06 \\
(\mathrm{~N}=180)\end{array}$ & 1.14 & $\begin{array}{c}3.40 \\
(\mathrm{~N}=95)\end{array}$ & 0.89 & $2.72 * *$ \\
\hline $\begin{array}{l}\text { The teacher activated me so that my } \\
\text { curiosity concerning the course subject } \\
\text { increased. }\end{array}$ & $\begin{array}{c}3.22 \\
(\mathrm{~N}=180)\end{array}$ & 1.01 & $\begin{array}{c}3.32 \\
(\mathrm{~N}=95)\end{array}$ & 0.82 & 0.88 \\
\hline $\begin{array}{l}\text { I feel that I am able to use the new practical } \\
\text { knowledge acquired in the course. }\end{array}$ & $\begin{array}{c}3.22 \\
(\mathrm{~N}=180) \\
\end{array}$ & 1 & $\begin{array}{c}3.4 \\
(\mathrm{~N}=95)\end{array}$ & 0.88 & 1.59 \\
\hline $\begin{array}{l}\text { I enjoyed working on the computer and I surf } \\
\text { internet sites in the course subject. }\end{array}$ & $\begin{array}{c}2.54 \\
(\mathrm{~N}=97)\end{array}$ & 1.4 & $\begin{array}{c}3.23 \\
(\mathrm{~N}=36)\end{array}$ & 0.99 & $2.98 * *$ \\
\hline $\begin{array}{l}\text { Watching films/presentations in the course } \\
\text { were relevant and important for } \\
\text { understanding the topics covered in the } \\
\text { course. }\end{array}$ & $\begin{array}{c}3.23 \\
(\mathrm{~N}=141)\end{array}$ & 1.12 & $\begin{array}{l}3.41 \\
(\mathrm{~N}=82)\end{array}$ & 0.87 & 1.36 \\
\hline $\begin{array}{l}\text { The teacher encouraged me to think and } \\
\text { therefore I expanded my knowledge. }\end{array}$ & $\begin{array}{c}3.18 \\
(\mathrm{~N}=180)\end{array}$ & 1.04 & $\begin{array}{l}3.35 \\
(\mathrm{~N}=95)\end{array}$ & 0.88 & 1.44 \\
\hline
\end{tabular}




\begin{tabular}{|l|c|c|l|l|l|}
\hline $\begin{array}{l}\text { The trips/observations/visits to museums } \\
\text { contributed to me and expanded my } \\
\text { knowledge in the subject. }\end{array}$ & $\begin{array}{c}2.92 \\
(\mathrm{~N}=92)\end{array}$ & 1.29 & $\begin{array}{l}3.23 \\
(\mathrm{~N}=44)\end{array}$ & 1.13 & 0.98 \\
\hline $\begin{array}{l}\text { The experiments/demonstrations/lectures } \\
\text { contributed to enrich my knowledge in the } \\
\text { subject. }\end{array}$ & $\begin{array}{c}3.2 \\
(\mathrm{~N}=169)\end{array}$ & 1.08 & $\begin{array}{l}3.31 \\
(\mathrm{~N}=58)\end{array}$ & 0.92 & 0.77 \\
\hline $\begin{array}{l}\text { Making surveys/projects/creative works } \\
\text { helped me gain a better understanding of the } \\
\text { subject. }\end{array}$ & $\begin{array}{c}3.04 \\
(\mathrm{~N}=161)\end{array}$ & 1.25 & $\begin{array}{l}2.96 \\
(\mathrm{~N}=79)\end{array}$ & 1.24 & 0.43 \\
\hline I enjoyed working on group projects. & $\begin{array}{c}3.17 \\
(\mathrm{~N}=180)\end{array}$ & 1.12 & $\begin{array}{l}3.09 \\
(\mathrm{~N}=95)\end{array}$ & 1.09 & 0.62 \\
\hline
\end{tabular}

$\mathrm{p}<0.05^{*} \quad \mathrm{p}<0.01 * *$

Table 2 shows that among humanities pupils, the average level of agreement for three of the five statements related to the learning experience is significantly higher (3.47 to 3.65) compared to the sciences (3.26 to 3.49). The difference between the two groups with respect to the standard deviation is more significant. The group that studied humanities was more homogeneous ( 0.59 to 0.75 ) than that of group studying science and technology (0.78 to 0.97). There is a significant difference between the two groups regarding the statement on the teacher's role, "The teacher encouraged me to learn in depth and research the course topics." In the humanities courses, the level of agreement among the pupils was higher $(\mathrm{Mz}=3.40)$ and there was a smaller standard deviation $(\mathrm{Sd}=0.89)$ compared to pupils studying the sciences $(\mathrm{Mz}=3.06, \mathrm{Sd}=1.14)$.

The pupils that studied science and technology agreed to a large degree with the statements relating to the teaching methods, but showed a wider range in the level of agreement. Statements relating to the teaching methods within the humanities courses were also agreed with to a great extent. There were also statements where the scores of the degree of agreement were higher among pupils studying humanities as compared to the pupils of the second group such as "I enjoyed working on the computer," and "I surf internet sites in the course subject" $(\mathrm{Mz}=3.23 \mathrm{vs} . \mathrm{Mz}=2.54)$. "Watching films/presentations in the course were relevant and important for understanding the topics covered in the course" ( $\mathrm{Mz}=3.41$ compared to $\mathrm{Mz}=3.23$ ). "The trips/observations/visits to museums contributed to me and expanded my knowledge in the subject" $(\mathrm{Mz}=3.23$ vs $\mathrm{Mz}=2.92)$. "The experiments/demonstrations/lectures contributed to enrich my knowledge in the course subject" $(\mathrm{Mz}=3.31$ compared to $\mathrm{Mz}=3.20)$. There is a significant difference concerning the statement "I enjoyed working on the computer and I surf internet sites in the course subject." Regarding the statement, "I learned topics within the course with different teaching methods than at school," the degree of agreement of the humanities pupils was lower than that of the science pupils $(\mathrm{Mz}=3.28 \mathrm{vs} \mathrm{Mz}=3.43)$. The degree of agreement regarding the other statements was similar in the two groups.

Table 3 shows the types of activities that the pupils perceived as being challenging within the framework of the courses at Hugordon. 
Table 3

Activities that challenged gifted pupils at Hugordon

\begin{tabular}{|c|c|c|c|}
\hline Type of activity & $\begin{array}{l}\text { Both } \\
\text { Groups } \\
\qquad \mathrm{N}=275\end{array}$ & $\begin{array}{l}\text { Science and } \\
\text { Technology } \\
\qquad \mathrm{N}=180\end{array}$ & $\begin{array}{r}\text { Humanities } \\
\mathrm{N}=95\end{array}$ \\
\hline Model building & $29.4 \%$ & $32.8 \%$ & $22.2 \%$ \\
\hline Experiments & $17.3 \%$ & $24.9 \%$ & $2.3 \%$ \\
\hline Visual aids & $17 \%$ & $16.3 \%$ & $20.8 \%$ \\
\hline $\begin{array}{l}\text { Learning through } \\
\text { situations }\end{array}$ & $7.5 \%$ & $3.2 \%$ & $16.7 \%$ \\
\hline $\begin{array}{l}\text { Preparing an article/ } \\
\text { speech/presentation }\end{array}$ & $7.4 \%$ & $1 \%$ & $15.7 \%$ \\
\hline Field trips & $4.7 \%$ & $4.3 \%$ & $6 \%$ \\
\hline Riddles & $4.5 \%$ & $5 \%$ & $2.8 \%$ \\
\hline Games & $4 \%$ & $4.3 \%$ & $3.2 \%$ \\
\hline $\begin{array}{l}\text { Watching } \\
\text { films/presentations }\end{array}$ & $2.5 \%$ & $2.5 \%$ & $2.3 \%$ \\
\hline Group activities & $1.8 \%$ & $1.4 \%$ & $2.8 \%$ \\
\hline Online research & $1.8 \%$ & $1.4 \%$ & $2.8 \%$ \\
\hline Observations & $1.4 \%$ & $2 \%$ & $0 \%$ \\
\hline Analyzing data & $1 \%$ & $1 \%$ & $0 \%$ \\
\hline Surveys & $1 \%$ & $0 \%$ & $1.9 \%$ \\
\hline
\end{tabular}

The answers of all pupils (both groups) show that $63 \%$ of the activities that challenged them included building models, experiments, and activities involving visual aids. Activities related to learning through situations and preparing an article/speech/presentation were perceived as being less challenging by the pupils. The most challenging activities in the science and technology courses ( $74 \%$ ) included building models, experiments and activities involving visual aids. Activities such as riddles, field trips, and games were less challenging in the science and technology courses. The most challenging activities in the humanities courses (75\%) included building models, learning through situations, preparing an article/speech/presentation, visual aids and activities. Less challenging activities were field trips, games, and experiments.

Comparative analysis of challenging activities in both fields shows that there is no relation between the challenging activities perceived by science pupils and humanities pupils. A greater proportion of science pupils were challenged by model building $(32.8 \%)$ than humanities pupils $(22.2 \%)$. A comparison between the two groups shows that $24.9 \%$ of science pupils considered experiments as a challenging task, compared with only $2.3 \%$ of humanities pupils. Another large difference is found with the activities associated with 
learning through situations. Only $3.2 \%$ of science pupils found this activity as being challenging as compared with $16.7 \%$ of humanities pupils. There is also a significant difference between the two groups regarding activities relating to preparing an article/speech/presentation. Only $1 \%$ of science pupils considered this a challenging activity, compared to $15.7 \%$ of humanities pupils.

The type of activities that were challenging to the pupils according to the course types was found to be significantly different when examined by the chi-square test

$$
\left(\chi^{2}(13)=23.68, \mathrm{p}<.0001\right) \text {. }
$$

\section{Discussion and Conclusions}

The present study was designed to test attitudes of pupils who attend a program for gifted and talented children towards teaching methods, learning experience, and the role of the teacher. This research identified those activities perceived as challenging by the pupils, and compared the attitudes of science pupils to humanities pupils towards teaching methods, learning experience, and the teacher's role. The discussion integrates the findings with different thinking styles according to Sternberg (1997).

The findings showed that the pupils had a considerably high to very high level of satisfaction from the learning experience within the courses. The findings also indicated that the science pupils were challenged by activities that encouraged analytical and practical thinking more than the humanities pupils. A high level of satisfaction with the performance of the teacher was found, and results revealed that performance management and teaching methods used in class were significant to the pupils.

There was also a high to very high level of satisfaction regarding the learning experience within the courses. Research findings indicated that the role of the teacher in managing the lesson and teaching methods were important to the pupils. However, pupils expressed a wider range of satisfaction regarding teaching methods as compared to learning experience, and the teacher's role. As part of the framework in Hugordon, teachers adapt their teaching styles of gifted and talented pupils and apply them in a wide variety of teaching methods. The literature indicates that not all thinking styles are suitable for gifted and talented pupils and therefore these pupils expressed satisfaction levels on a wider level range. The pupils learning experience within the courses was discovered as a product of significant learning occurring in and outside of the classroom.

In the learning process within the courses, the pupils were exposed to a variety of teaching methods. The research findings show that the level of agreement among the pupils about the learning experience and the role of teacher were high, as shown in Table 1. Another finding shown in Table 1 is the diverse level of agreement relating to teaching methods, indicating a wide range of pupils' thinking styles.

The sample population preferred challenging tasks that encouraged analytical and practical thinking according to Sternberg's model (1998). Pupils preferred the challenging activities that encouraged analytical and practical thinking more than challenging activities that encouraged creative thinking.

Examples of activities that encouraged practical thinking included building geometric forms in the Mathematical Thinking course, experiments with gelatin and eggs in the Magic and Science course, and building models and designs in both the Robotics course (sensors, elevators, and gears) and the Aerodynamics and Space course (space shuttle and aircraft). Other examples promoting practical thinking were field trips, observations, contests, and games.

Examples encouraging analytical thinking included riddles, activities, visual aids, data analysis and surveys, worksheets, discussions, watching movies, presentations, internet surfing, construction programs in the Robotics and the Aerodynamics and Space courses, 
group work, experiments in the Young Veterinarian course (e.g., dissection of a chicken heart to understand blood circulation).

Examples of activities that encouraged creative thinking were preparing an article, presentation or speech, comics and animation activities, playing Dungeons \& Dragons, building free models in the Robotics course, building models with clay, healing pots and using tools of prehistoric man in the Archeology course.

In cases of mixed activities, such as building a product, the activities were classified more than once - in both encouraging practical thinking and encouraging creative thinking. Findings showed that the teachers' role, a rich learning experience, and using a variety of teaching methods including inquiry methods caused pupils to rate their attitudes to the learning experience as high.

Findings relating to the satisfaction level of the pupils enrolled in the various courses confirmed the findings of Vialle and Quigley (2002), in which the learning experience was based on teaching methods that included a wide range of activities led by the teacher. These findings also reinforced Hoffman's (1998) findings that children, like adults, are able to record experiences that affect their lives. These experiences occur spontaneously at different moments, and generally are not deleted from memory.

Challenging tasks in the humanities courses, such as preparing an article, speech, newspaper, and producing a presentation were more important to the humanities pupils than the science pupils, indicating that humanities pupils felt challenged by activities that encouraged creative thinking. Challenging activities in the science courses, such as experiments, and building and designs, were considered of greater importance in the eyes of the science pupils, indicating that pupils studying science and technology were challenged by activities that encouraged analytical and practical thinking (Sternberg, 1998).

Creative thinking allowed humanities pupils to use research skills, imagination, and discovery. Indeed, most of the activities in the humanities courses encouraged these skills. Creative thinking is intuitive. It is concerned with discovery, invention, imagination, and speculation, which are related to the ability to deviate from the given and generate new and interesting ideas, even if they were raised unintentionally or "off the cuff". Creative thinking also tends to examine what is the least likely to occur (Weinberger \& Zohar, 2005). In these courses, teachers encouraged the pupils to look for creative ways to solve tasks. The findings indicated that this group perceived the learning experience and the teacher's role as being more important than participants in the science and technology courses.

\section{Conclusion}

The current study described attitudes of gifted and talent pupils towards the learning experience, the role of the teacher, and the teaching methods in enrichment courses. The types of activities that pupils found most challenging were reviewed, and differences in pupils' perceptions of the learning experience according to the types of specialties were examined. These results indicated that an enriched learning experience and the teacher's role are the basic conditions for the development of inquiry learning methods for gifted and talented pupils. As for the types of activities, the pupils preferred activities related to the preparation of products (such as building models), suggesting that the development of practical thinking and performing experiments encouraging analytical thinking.

The humanities pupils showed a higher degree of agreement with statements relating to the learning experience and the teacher's role than the science pupils. The findings also indicated that pupils specializing in humanities courses were challenged by activities relating to the implementation of an article/paper/presentation and building models - activities that encouraged creative thinking. It is thus recommended to encourage more activities that develop 
creativity in the science and technology courses, and develop more analytical and practical activities in the humanities courses.

The trend in education today is to encourage pupils towards research activities, to search for information in order to understand the world around them, to direct the learning towards building ideas and not memorization of information. Such learning is based on higher order thinking skills and requires the teacher to instruct in a creative manner. It seems that within the range of activities that take place in Hugordon, gifted and talented pupils have a greater degree of exposure to a wide variety of teaching methods that reflect different thinking styles than pupils attending traditional schools within the framework of formal education. The teaching methods and learning contents used by the teachers may be useful in designing enrichment programs for different settings. The findings of the present study therefore have implications for wider curriculum planning, and we believe that the teaching methods and activities in Hugordon can serve as a world-wide model.

\section{Bibliography}

Bruner, J. S. (1960). The process of education. New York: Vintage.

Deci, E. L., Nezlek, J., \& Sheinman, L. (1981). Characteristics of the rewarder and intrinsic motivation of the rewardee. Journal of Personality and Social Psychology. 40, 1-10.

Dewey, J. (1938). Experience and education. New York: Collier.

Doyle, W. (1986). Classroom organization and management. In M. C. Wittrock (Ed.), Handbook of Research on Teaching ( $4^{\text {th }}$ Edition). New York: MacMillan.

Eilam, B., \& Vidergor, H. E., (2011). Gifted Israeli students' perceptions of teachers desired characteristics: A case of cultural orientation. Roeper Review, 33, 86-96.

Gruber, S., \& Jean, B. (2003). Teaching critical thinking: Using experience to promote learning in middle schools and college students. Teacher and Teaching: Theory and Practice, 9(1), 5-19.

Freire, P. (1981). Pedagogy of the Oppressed. Jerusalem: Mifras (in Hebrew).

Hennessey, B. A. (2004). Developing creativity in gifted children: The central importance of motivation and classroom climate. Wellesley, Mass: The National Center on the Gifted and Talented.

Hoffmann, E. (1998). Peak experiences in childhood: An exploratory study. Journal of Humanistic Psychology, 38(1), 109-120.

Gardner, H. (1993). Multiple intelligences: The theory in practice. New York: Basic Books.

Gordon, D., Levin - Rozalis, M. Keenan, E. (2003). Inquiry projects in elementary school. Research Report submitted to Chief Scientist of the Ministry of Education. Beer Sheva: Ben Gurion University (in Hebrew).

Kubovy, D. (1978). Between teacher and pupil: Pupils perception of a good teacher. Tel Aviv: Poalim Library (in Hebrew).

Maslow, A. (1968). Some educational implications of the humanistic psychologies Harvard Educational Review, 38, 685-696.

Rogers,K. (1973). Freedom to learn. Tel Aviv: Poalim Library (in Hebrew).

Rogers, K. (2007). Lessons learned about educating the gifted and talented. The Gifted Child Quarterly 51(4), 382-396.

Rowley, J. (2002). Teacher effectiveness in the education of gifted students: A comparison of trained trainee and untrained teachers of gifted and talented students. (Unpublished doctoral dissertation). University of South Wales, Sydney. Australia.

Smith, J. (2002). Learning style: Fashion fad or lever for change? The applications of 
learning style theory to inclusive curriculum delivery. Innovation in Education and Teaching International, 39(1), 63-70.

Sternberg, R. (1985). Beyond IQ. Cambridge, MA: Cambridge University Press.

Sternberg, R. (1997). Thinking styles. Cambridge, MA: Cambridge University Press.

Sternberg, R. (1998). Successful Intelligence - Beyond IQ. Jerusalem: Branco Weiss Institute (in Hebrew).

Van Tassel-Baska, J., Feldhusen, J., Seeley, K., Wheatley, G., Silverman, L, \& Foster, W., (1988). Comprehensive curriculum for gifted learners. Needham Hights, MA: Allyn \& Bacon.

Van Tassel-Baska, J. MacFarlene, B., \& Feng, A. X. (2006). A cross- cultural study of exemplary teaching: What do Singapore and United States secondary gifted class teachers say? Gifted and Talented International, 21(2), 38-47.

Vialle, W., \& Quigley, S. (2002). Does the teacher of the gifted need to be gifted? Gifted and Talented International, 17(2), 85-90.

Weinberger, Y. Zohar, A. (2005). Thinking development - a challenge to teacher training. Tel Aviv: Mofet Institute (in Hebrew).

Yair, G. (2003). Decisive moments and key experiences: Expanding paradigmatic boundaries in the study of school effects. In C. A. Torres, \& A. Antikainen (Eds.), The international handbook on the sociology of education: An international assessment of new research and theory (124-142). Lanham, MD :Rowman \& Littlefield.

Yair, G. (2006). The strength of the educational effect, from key experiences to turning points in life - implications of a new science. Tel Aviv: Poalim Library (in Hebrew).

Yair, G. (2008). Can we administer the scholarship of teaching? Lessons from outstanding professors in higher education. High Educ., 55, 447-451.

Zohar, A. (1996). Learning, thinking and learning to think. Jerusalem: Branco Weiss Institute (in Hebrew).

Zohar, A. (ed.). (2006). Inquiry-type learning: a continuing challenge. Jerusalem: Magnus (in Hebrew).

Zorman R, Rachmal S. Shaked A (2004), Principles for developing unique programs for gifted students. Jerusalem: Ministry of Education (in Hebrew). 